\title{
CCCV. THE PURIFICATION OF CHOLINE-ESTERASE.
}

\author{
By EDGAR STEDMAN AND ELLEN STEDMAN. \\ From the Department of Medical Chemistry, University of Edinburgh.
}

(Received September 12th, 1935.)

\begin{abstract}
ALthough it was previously known from pharmacological experiments, quoted in our earlier papers, that certain body fluids brought about the enzymic decomposition of small amounts of acetylcholine, the first demonstration of the existence of a specific enzyme which catalyses the hydrolysis of this ester, as well as of other esters of choline, was that of Stedman et al. [1932] who termed the enzyme in question choline-esterase. This demonstration depended primarily upon the discovery that whereas purified preparations of certain known esterhydrolysing enzymes, such as liver esterase and pancreatic lipase, were unable to accelerate the hydrolysis of esters of choline to an extent detectable by chemical means, blood serum from the horse readily effected such an acceleration, a result which was so definite and of such a convincing nature that further work on the subject could hardly be other than of a corroborative kind. This has, in fact, proved to be the case, ample corroboration of the original conclusions of Stedman et al. [1932] being offered by the work of Stedman et al. [1933] and of Ammon [1934]. Nevertheless there remained some doubt as to the degree of specificity of choline-esterase, for blood serum from the horse, which was usually employed as source of the enzyme in question, exhibited a pronounced enzymic activity towards other types of esters, in particular towards methyl butyrate, and it was therefore uncertain whether part of this activity might not be due to choline-esterase. Stedman et al. [1932], in their original work on this subject, had examined this problem to some extent. They succeeded in effecting a considerable purification of the enzyme and were able to show that, as purification proceeded, the activity of the preparation towards methyl butyrate diminished considerably relatively to its activity towards esters of choline. But they did not succeed in obtaining preparations which were completely devoid of activity towards simple esters, thus leaving open the possibility that choline-esterase might exhibit a small activity towards such esters. Further evidence on this point, depending upon a much more extensive purification of the enzyme, has now been obtained and is described in the present communication.
\end{abstract}

\section{Preliminary purification of choline-esterase.}

In the work here described blood serum from the horse has formed the source of choline-esterase, and it has been found necessary to submit this to a preliminary purification by fractional precipitation with ammonium sulphate. The experimental basis of this method of purification has already been described by Stedman et al. [1932]. In the course of the last three years, however, much experience has been gained in working up large volumes of serum and this has enabled us to define with much greater precision than before the conditions necessary for the successful application of the method. By using the Sharples "supercentrifuge", which, in fact, appears to be practically indispensable for the process, large volumes of serum can be readily and successfully worked up. 
The procedure finally adopted is as follows. $250 \mathrm{~g}$. of ammonium sulphate are dissolved in 1 litre of horse serum. The precipitate is removed and rejected, whilst the centrifugate is treated with further ammonium sulphate at the rate of $15 \mathrm{~g}$. per $100 \mathrm{ml}$. When this has dissolved, $0 \cdot 5 \mathrm{~N}$ acetic acid is added slowly and with stirring, $78 \mathrm{ml}$. being employed for the centrifugate from 1 litre of serum. The mixture is now allowed to stand for $2 \frac{1}{2}-2 \frac{3}{4}$ hours, after which the precipitate, which contains the bulk of the enzyme, is centrifuged off and the enzyme eluted from it with $300-400 \mathrm{ml}$. of a solution containing $350 \mathrm{~g}$. of ammonium sulphate in 1 litre of water. The eluate is now separated and kept for a few hours or, if convenient, overnight. During this time a precipitate usually forms, in which case it is removed and rejected. The centrifugate from this last process is measured and treated with solid ammonium sulphate $(5 \mathrm{~g}$. per $100 \mathrm{ml}$.) and sufficient $0.5 \mathrm{~N}$ acetic acid (about $5 \mathrm{ml}$.) to render it faintly acid to litmus. The enzyme separates with the precipitate. After about $30 \mathrm{~min}$. the material is centrifuged, the solid dissolved in the smallest possible volume of water and the solution so obtained dialysed in collodion membranes against water saturated with chloroform until free from ammonium sulphate. The product, after removal of some protein which separates during dialysis, consists of about $50 \mathrm{ml}$. of a clear solution which varies, in different batches, from light to dark brown in colour according to the amount of haemoglobin contained in the serum from which it was prepared. Its choline-esterase activity is from 4 to 6 times that of the original serum, so that the yield of enzyme is approximately $20 \%$. The activity of the preparation can be conveniently and accurately determined by the titration method of Stedman et al. [1933] using bromothymol blue as indicator and, preferably, butyrylcholine as substrate, since, of the choline esters so far examined, this ester is hydrolysed the most rapidly by choline-esterase. Having determined the activity of the preparation, the degree of purification effected can be readily ascertained by evaporating $1 \mathrm{ml}$. to dryness on a water-bath, weighing the solid residue and hence calculating the "weight number" of the preparation. For the purposes of the present work we define the weight number of a preparation as the number of ml. of $0.02 \mathrm{~N}$ sodium hydroxide required to neutralise the butyric acid liberated at $30^{\circ}$ from butyrylcholine in $20 \mathrm{~min}$. at $p_{\mathrm{H}} \mathbf{7 \cdot 4}$ by the cholineesterase associated with $1 \mathrm{~g}$. of the solid material contained in the preparation, the actual titration being carried out under the conditions described in our earlier publications. For example, in an actual preparation the butyric acid liberated in $20 \mathrm{~min}$. by $0.25 \mathrm{ml}$. of the final solution required $9.8 \mathrm{ml}$. of $0.02 \mathrm{~N}$ alkali for neutralisation, whilst $1 \mathrm{ml}$. of the solution yielded on evaporation $0.078 \mathrm{~g}$. of solid residue. The weight number of the preparation was thus $9 \cdot 8 \times 4 / 0 \cdot 078=503$. The corresponding figure for the original serum cannot be determined accurately at $p_{\mathrm{H}} \mathbf{7 \cdot 4}$, but if a value of 100 , which is a maximum figure, be assumed it is evident that the process has resulted in at least a 5-fold purification of the enzyme. This degree of purification is an average one. Occasionally it is somewhat smaller; at times much greater. Thus, final products have been obtained with weight numbers ranging from about 300 to 1500 . Preparations of this type retain their activity for months if stored in a refrigerator but deteriorate moderately rapidly if kept at room temperature.

Certain details of the above process are susceptible of considerable modification without significantly influencing the final result. Thus, it appears to be immaterial whether the first precipitation is made with 250 or $200 \mathrm{~g}$. of ammonium sulphate per litre of serum, provided, in the latter case, that the second precipitation is made with $20 \mathrm{~g}$. of ammonium sulphate per $100 \mathrm{ml}$. of centrifugate. On the other hand, much care must be exercised with respect to the acidification at 
the second stage. It is, in fact, upon this process that the success of the operation mainly depends. The use of too high a concentration of acid leads to a diminution both in the yield and the purity of the product, whilst with toolow a concentration the degree of purification is small. The time factor is of equal, if not greater, importance. If the acidified material is worked up after too short an interval of time, little purification is achieved; with too great an interval, the yield is curtailed and the purity diminished. We interpret these results as indicating that the function of the acetic acid is to denature part of the protein and so render it insoluble in the ammonium sulphate solution used for the elution of the enzyme. Such denaturation must be as extensive as possible, provided it is not pushed beyond the limits at which sufficient soluble protein remains to act as a carrier for the enzyme.

\section{Purification of choline-esterase by adsorption.}

Attempts to adsorb the enzyme directly from serum completely failed, as is illustrated by the following experiment. About $30 \mathrm{ml}$. of serum were shaken with fuller's earth and centrifuged. The centrifugate $(27 \mathrm{ml}$.) was made distinctly acid to litmus by the addition of $1.2 \mathrm{ml}$. of $0.5 \mathrm{~N}$ acetic acid, shaken with $1 \mathrm{~g}$. of kaolin and again centrifuged. The new centrifugate $(23 \mathrm{ml}$.) was then treated with $4 \mathrm{ml}$. of a suspension of aluminium hydroxide and the latter removed. At each stage a determination was made of the weight number of the centrifugate, the titration being made at $p_{\mathrm{H}} 8.0$, with the following results: serum, 61.5 ; after fuller's earth, 73.1; after kaolin, 81.5; after alumina, 85.2. The corresponding titration figures were $6 \cdot 5,7 \cdot 35,7 \cdot 1$ and $6 \cdot 05 \mathrm{ml}$. respectively. In no case was any enzyme removed by the adsorbent, the diminution in the titration figure for the last centrifugate being accounted for by the dilution caused by the addition of the suspension of alumina. A small but steady increase in purity occurred, however, at each stage. That produced by the fuller's earth was evidently partly due to the removal of inactive material and partly to the removal of an inhibitor, whilst that caused by the kaolin and alumina was due solely to the former process. The effect of fuller's earth in increasing the activity of serum has also occasionally been observed with preparations made by the process described in the preceding section, but the effect is not a constant one with such preparations.

In view of the foregoing results subsequent adsorption experimonts have been made with purified preparations of the enzyme. These have resulted in the demonstration that choline-esterase can be removed from such solutions by alumina provided they have first been rendered distinctly acid to litmus by the addition of acetic acid. Kaolin, however, is ineffective either in alkaline or acid solution. Removal of the enzyme from the alumina adsorbate can be effected either by treatment with $0.025 \mathrm{~N}$ ammonia or with phosphate buffer of $p_{\mathrm{H}} 8 \cdot 0$. The former eluent sometimes fails, particularly when adsorption has been made from a preparation which has already been purified by adsorption, but the phosphate buffer is always effective if used in sufficient quantity and high enough concentration. One disadvantage of the latter eluent is that the activity of the eluate cannot be measured until the phosphate has been removed by dialysis, for, in the concentration which it is necessary to employ, it exerts a pronounced inhibitory action on choline-esterase. Purification by these means is illustrated by the following example.

$50 \mathrm{ml}$. of a preparation of choline-esterase of weight number 450 were made acid by the addition of 6 drops $(0 \cdot 3 \mathrm{ml}$.) of $0.5 \mathrm{~N}$ acetic acid, $6 \mathrm{ml}$. of a suspension of aluminium hydroxide were then added slowly, with continuous shaking, and the mixture was centrifuged. Previous experience enabled us to judge from 
the colour of the centrifugate that adsorption of the enzyme was incomplete. It was therefore similarly treated with $5 \mathrm{ml}$. of a suspension of ferric hydroxide and again centrifuged. Adsorption was still obviously incomplete. The centrifugate was therefore mixed with a further $5 \mathrm{ml}$. of alumina, after which $0.25 \mathrm{ml}$. of the centrifugate gave a titration figure of $1.5 \mathrm{ml}$. as compared with $8.2 \mathrm{ml}$. for the original preparation. A final adsorption with $10 \mathrm{ml}$. of the alumina suspension was therefore carried out. The centrifugate, which now measured $75 \mathrm{ml}$., still contained some enzyme as shown by the titration figure, using $0.25 \mathrm{ml}$. of the centrifugate, of $0.85 \mathrm{ml}$. in $20 \mathrm{~min}$.; this represented about $15 \%$ of the enzyme present in the original preparation.

The various alumina adsorbates were united and washed with an equal volume of water. They were then stirred with $20 \mathrm{ml}$. of $0.025 \mathrm{~N}$ ammonia, allowed to stand for 1 hour, and centrifuged. The ferric hydroxide adsorbate was similarly eluted with $5 \mathrm{ml}$. of the ammonia solution. Both eluates were active and of similar degrees of purity, as shown by the following quantitative data: alumina eluate, weight number 1833, titration figure for $0.25 \mathrm{ml} .5 .5 \mathrm{ml}$.; ferric hydroxide eluate, weight number 1766, titration figure $3.0 \mathrm{ml}$. From this one experiment ferric hydroxide appears to be as efficient an adsorbent for choline-esterase as is aluminium hydroxide, but it nevertheless offers no advantage over the latter and has therefore not been used in further work.

The eluate from the alumina adsorbate was acidified and the enzyme again adsorbed on alumina, $8 \mathrm{ml}$. of the suspension being required. Elution from the washed adsorbate was effected with $10 \mathrm{ml}$. of $M / 3$ phosphate buffer of $p_{\mathrm{H}} 8 \cdot 0$. After dialysis, the preparation had a weight number of $3098,0.25 \mathrm{ml}$. giving a titration of $6.35 \mathrm{ml}$. A final adsorption was now made with $4 \mathrm{ml}$. of alumina, this effecting the complete removal of the enzyme from the last eluate. In this instance the adsorbate was washed with a few ml. of $0.025 \mathrm{~N}$ ammonia and then eluted with $10 \mathrm{ml}$. of phosphate buffer. The ammonia washings were, however, found to be active, $0.25 \mathrm{ml}$. giving a titration figure of $5.75 \mathrm{ml}$. whilst the weight number proved to be 4423 . The dialysed phosphate eluate had a weight number of 3083 (titration: $0.5 \mathrm{ml}$. required $3.7 \mathrm{ml}$. alkali) and thus showed no improvement as regards purity over the solution from which it was prepared.

The foregoing example is not the most successful purification by adsorption which we have carried out, but it has been quoted because it best illustrates the various processes involved. Whilst it must be emphasised that, in applying the adsorption method to choline-esterase, the efficiency of the method must be checked at each stage, it might here be pointed out that the best results are usually obtained by adsorbing the enzyme on alumina, eluting it with ammonia; and repeating these processes until the latter eluent is ineffective. Elution can then be made with phosphate. In one instance this procedure was exceedingly effective, the ammonia eluate from the first adsorption having a weight number of 2267 as compared with 675 for the original preparation. A second adsorption gave an adsorbate from which the enzyme could no longer be eluted with ammonia, but, using phosphate, a product was readily obtained with a weight number of 5647 .

\section{Specificity of choline-esterase.}

Many specimens of choline-esterase purified by adsorption have been examined for possible activity towards methyl butyrate, but in no case has such activity been detected. Thus, using $0.25 \mathrm{ml}$. of a preparation of weight number 3098 with $0.25 \mathrm{ml}$. of methyl butyrate dissolved in $100 \mathrm{ml}$. of water at $30^{\circ}$ as substrate, $0.25 \mathrm{ml}$. of $0.02 \mathrm{~N}$ alkali was required to maintain the $p_{\mathrm{H}}$ of the solu- 
tion at $\mathbf{7 . 4}$ for $20 \mathrm{~min}$.; the same volume of alkali was required in a blank experiment without enzyme. On the other hand, with butyrylcholine as substrate under the usual conditions $6.35 \mathrm{ml}$. of alkali were required. Similar results were obtained with the preparation, mentioned above, of weight number 5647. It must be concluded that choline-esterase has no significant action on methyl butyrate.

\section{SUMMARY.}

Choline-esterase cannot be adsorbed directly from blood serum from the horse by adsorbents such as aluminium hydroxide, but by submitting the enzyme to a preliminary purification by a process which consists essentially of fractional precipitation with ammonium sulphate combined with partial denaturation of the serum proteins by means of acetic acid, preparations can be obtained which are susceptible of further purification by adsorption. Among the adsorbents examined, aluminium and ferric hydroxides were found to take up the enzyme from acid, but not from neutral or faintly alkaline, solutions. Kaolin is totally ineffective. Elution from the adsorbates can usually be made with $0.025 N$ ammonia. As purification proceeds, however, this eluent ceases to be effective. Elution can then be carried out with $M / 3$ phosphate buffer of $p_{\mathrm{H}} 8 \cdot 0$.

Preparations of choline-esterase the purity of which is from 50 to 100 times that of serum have been made by the above methods. Such preparations have no detectable activity towards methyl butyrate.

The expenses of this investigation have been partly met by grants from the Earl of Moray Research Fund of Edinburgh University.

\section{REFERENCES.}

Ammon (1934). Pfluger's Arch. 233, 486.

Stedman, Stedman and Easson (1932). Biochem. J. 26, 2056.

- and White (1933). Biochem. J. 27, 1055. 